\title{
Deviations from the Basic Distribution of Communicative Dynamism as a Style Marker
}

\begin{abstract}
The article compares academic prose and fiction from the viewpoint of deviations from the basic distribution of communicative dynamism, i.e. the ordering theme - transition - rheme. The aim of the comparison is to ascertain whether non-compliant word order configurations can serve as a style marker. According to previous studies it is assumed that the two text sorts will differ not only in the representation of the basic distribution of $\mathrm{CD}$ and deviations from it, but also in the types of non-compliance, which are expected to reflect the different character and subject matter of the examined text sorts: fiction is assumed to display more deviations from the basic distribution in the postverbal orderings, whereas academic prose in the preverbal configurations.
\end{abstract}

Key words

Functional sentence perspective; communicative dynamism; basic distribution; fiction; academic prose

\section{Introduction}

This article is a probe into the question whether different types of deviation from the basic distribution of communicative dynamism can characterize different text sorts, here fiction and academic prose. The concept of basic distribution of communicative dynamism, just as the entire theoretical framework of the article, is based on the theory of functional sentence perspective developed by Jan Firbas (1992). In this theory, basic distribution of communicative dynamism is defined as the arrangement of sentence elements in accordance with a gradual rise in communicative dynamism, i.e. in the sequence theme - transition - 
rheme (Firbas 1992:118). In English linguistic literature (Quirk et al. 1985; Halliday 1994; Leech 1983), this concept has a partial counterpart in the term "end focus," which coincides with basic distribution of communicative dynamism in one fundamental point. Both terms reflect the universal principle of the organization of information structure, viz. the placement of the novel or most important part of a communication at the end of an utterance. Accordingly, what will be said about deviations in the postverbal position, which mostly displays novel information, equally applies to violation of the principle of end focus. The conception of the preverbal position, however, differs in the Czech and the English approach, even though this position mostly contains informationally least important items. In the English approach the initial position in a sentence is the defining feature of the theme. In contrast, the FSP theory defines the theme as the element carrying the lowest degree of communicative dynamism (amount of information, information load); vice versa, the same applies to the rheme, defined as the element carrying the highest degree of communicative dynamism. Most importantly, both in the case of the theme and the rheme, these definitions apply regardless of the sentence position of the respective element (Firbas 2010). Hence what will be said about the thematic section basically differs from the British conception.

Basic distribution of communicative dynamism, i.e. the arrangement of sentence elements according to a gradual rise in communicative dynamism, has been termed interpretative arrangement (Firbas 1992: 12-13), in contrast to their actual arrangement as they appear in the sentence, which may differ from the basic distribution. Differences in the two arrangements arise in consequence of the fact that basic distribution of communicative dynamism is neither the only word order principle, nor the only FSP factor. A major word order principle that may act counter to the basic distribution of communicative dynamism is the grammatical principle; the extent of its operation varies, however, since it depends on the character of the grammatical system. As regards the operation of the other FSP factors that co-determine FSP structure, the degrees of communicative dynamism of sentence elements are assigned to them by an interplay of all FSP factors, linear modification, context, semantics and in speech intonation (Firbas 2010: 262-264; 1992: 148), not by any one of them alone. Unlike word order, whose character depends on the grammatical system of the respective language, the operation of context, semantics and intonation is not language specific.

As follows from these observations, the present discussion is concerned with the actual arrangement of sentence elements considered from the viewpoint of their interpretative arrangement. Of the three FSP functions, theme - transition - rheme, it is confined to the thematic and rhematic sections as it is these sections that are primarily connected with the initial and final sentence positions. In other words, the preverbal and postverbal parts of the sentence are examined in regard to whether they contain, respectively, thematic and rhematic elements as determined by all FSP factors. On this basis, the actual word order arrangements are classed as non-deviant or deviant from the basic distribution. The exclusion of 
the transitional section is due not only to its medial position but also to its more complex composition, which calls for a separate study.

The idea of investigating deviations from the basic distribution of communicative dynamism in two different text sorts suggested itself in connection with the characteristic features of academic prose, as compared with the very diverse picture presented by fiction. Academic style is generally described as highly condensed both with respect to form and content, hence lacking, as far as possible, redundancy. From the viewpoint of the organization of information structure, this presupposes adherence to the principle of end focus, which provides little ground for deviations from the interpretative arrangement of the components in the rhematic postverbal, mostly final section. Adherence to the principle of end focus also suggests that in academic prose, deviations from the basic distribution of communicative dynamism might be less frequent than in fiction. On the other hand it was assumed, on the basis of previous studies of presentation sentences in biblical narrative (Adam 2013a; 2013b: 70-71, 78-79) and academic prose (Rohrauer 2015: 148-151), that there might be more deviations in the preverbal, thematic section. According to these studies, biblical narrative and academic prose display a higher frequency than fiction of presentation sentences realized by initial rhematic subject - presentational verb - optional scene-setting element. Hence the assumptions in the present study of more deviations from the interpretative arrangement in the postverbal position (rhematic section) in fiction, of more deviations from the interpretative arrangement in the preverbal position (thematic section) in academic writing and, possibly, of altogether fewer deviations in academic writing.

As noted in the definitions of the theme and the rheme, coincidence of the thematic section with the preverbal position and of the rhematic section with the postverbal position applies only to the interpretative arrangement. In the actual arrangement thematic and rhematic elements may occur in any sentence position.

\section{Material and method}

The material on which the following discussion is based was drawn from two novels and two academic works: Paul Grisham, The Street Lawyer, P. D. James, Original Sin, Desmond Morris, The Naked Ape and Paul Davis's translation of W. Heisenberg's Physik und Philosophie. Except for P.D. James, the material was drawn from the InterCorp (InterCorp Books $<\mathrm{http}$ ://www.korpus.cz/intercorp $>$ (last accessed 6 November 2014). The examples from P.D. James were excerpted from the printed volume, hence include pagination.

The syntactic unit from which instances of deviation / non-deviation were excerpted was the clause (in syntactic terms a structure within the scope of one verb, whether finite or nonfinite; in FSP terms a clausal distributive field). Each sample was searched for 50 instances of deviations within the thematic and rhematic sections, so that the whole material consists of 200 instances, equally representing the 
two text sorts. In each sample, the measure of the frequency of occurrence of deviating clauses was the number of non-deviating clauses needed to obtain the 50 non-compliant examples in the respective sample. The search had to be done manually since computer corpora tagged for the FSP functions of clause elements are not available.

\section{Results}

3.1 The distribution of non-deviating and deviating clauses is shown in Table I. The non-deviating clauses are given in the column Ordering theme - rheme, the deviating clauses in the column Deviations from the basic distribution of communicative dynamism:

\begin{tabular}{|l|l|l|l|}
\hline & $\begin{array}{l}\text { Ordering } \\
\text { Th }-\mathrm{Rh}\end{array}$ & $\begin{array}{l}\text { Deviations from the basic distribution } \\
\text { of communicative dynamism }\end{array}$ & Total \\
\hline Grisham & $173(77.6 \%)$ & $50(22.4 \%)$ & $223(100 \%)$ \\
\hline James & $142(73.9 \%)$ & $50(26.1 \%)$ & $192(100 \%)$ \\
\hline Total & $\mathbf{3 1 5}(\mathbf{7 6 \% )}$ & $100(24 \%)$ & $\mathbf{4 1 5 ( 1 0 0 \% )}$ \\
\hline Morris & $107(68.1 \%)$ & $50(31.9 \%)$ & $157(100 \%)$ \\
\hline Davis & $108(68.2 \%)$ & $50(31.8 \%)$ & $158(100 \%)$ \\
\hline Total & $\mathbf{2 1 5}(\mathbf{6 8 . 3 \% )}$ & $100(31.7 \%)$ & $\mathbf{3 1 5}(\mathbf{1 0 0} \%)$ \\
\hline
\end{tabular}

Table 1. Representation of deviating and non-deviating orderings in fiction and academic prose

As shown by the figures, the assumption of fewer deviations in the academic sample was not confirmed. Academic prose appears to deviate from the basic distribution of communicative dynamism more often than fiction. Owing to the small size of the sample, this result may be accidental, and so is probably the close agreement between the two academic samples, even though oscillation about some average value can, in general, be expected to be smaller in this text sort as a concomitant feature of its relatively standardized character. On the other hand, the difference between the two fiction samples very likely reflects a general feature of fiction, variation and diversity being one of its characteristics.

3.2 The methodology for analyzing the deviations, summarily presented in Table 1 , was to classify them according to recurrent patterns, first in each sample separately, then collate them within the respective text sort, and finally make a comparison of the two text sorts. The results are presented in Table 2.

\begin{tabular}{|l|l|l|l|l|l|l|l|l|}
\hline $\begin{array}{l}\text { Types of } \\
\text { deviation }\end{array}$ & $\begin{array}{l}\text { Trans/Rh } \\
-\mathrm{Th}\end{array}$ & $\begin{array}{l}\text { Trans } \\
-\mathrm{Rh}-\mathrm{Th}\end{array}$ & $\begin{array}{l}\text { Trans } \\
-\mathrm{Th}-\mathrm{Rh}\end{array}$ & Initial Rh & $\begin{array}{l}\text { DiaTh } \\
-\mathrm{Th}\end{array}$ & $\begin{array}{l}\text { TransPrO } \\
-\mathrm{DiaTh}\end{array}$ & other & total \\
\hline Grisham & $17(34 \%)$ & $5(10 \%)$ & $17(34 \%)$ & $5(6 \%)$ & $4(8 \%)$ & - & $2(4 \%)$ & $50(100 \%)$ \\
\hline James & $12(24 \%)$ & $8(16 \%)$ & $18(36 \%)$ & - & $8(16 \%)$ & $2(4 \%)$ & $2(4 \%)$ & $50(100 \%)$ \\
\hline
\end{tabular}




\begin{tabular}{|l|l|l|l|l|l|l|l|l|}
\hline $\begin{array}{l}\text { Types of } \\
\text { deviation }\end{array}$ & $\begin{array}{l}\text { Trans/Rh } \\
-\mathrm{Th}\end{array}$ & $\begin{array}{l}\text { Trans } \\
-\mathrm{Rh}-\mathrm{Th}\end{array}$ & $\begin{array}{l}\text { Trans } \\
-\mathrm{Th}-\mathrm{Rh}\end{array}$ & Initial Rh & $\begin{array}{l}\text { DiaTh } \\
-\mathrm{Th}\end{array}$ & $\begin{array}{l}\text { TransPrO } \\
- \text { DiaTh }\end{array}$ & other & total \\
\hline Total & $29(29 \%)$ & $13(13 \%)$ & $35(35 \%)$ & $5(5 \%)$ & $12(12 \%)$ & $2(2 \%)$ & $4(4 \%)$ & $100(100 \%)$ \\
\hline Morris & $13(26 \%)$ & - & $10(20 \%)$ & $6(12 \%)$ & $9(18 \%)$ & $9(18 \%)$ & $3(6 \%)$ & $50(100 \%)$ \\
\hline Davis & $4(8 \%)$ & $4(8 \%)$ & $11(22 \%)$ & $2(4 \%)$ & $13(26 \%)$ & $13(26 \%)$ & $3(6 \%)$ & $50(100 \%)$ \\
\hline Total & $17(17 \%)$ & $4(4 \%)$ & $21(21 \%)$ & $8(8 \%)$ & $22(22 \%)$ & $22(22 \%)$ & $6(6 \%)$ & $100(100 \%)$ \\
\hline
\end{tabular}

Table 2. Recurrent patterns of deviations

As shown in Table 2, six patterns of deviations were detected, with a seventh group comprising miscellaneous instances with unclear FSP structure.

The pattern Trans/Rh - Th (29 instances in fiction, 17 in academic prose) contained a verb with the dual FSP function of Transition + Rheme, followed by a thematic element, object or adverbial.

(1) a. his calmness unnerved me (Grisham)

b. (Descartes tries to establish the order through some fundamental division. (But the three parts) which result from the division (Davis)

c. where we must stop for the moment (Morris)

The objects were mostly personal pronouns, as in (a). In the case of substantival objects the FSP function was determined on the basis of the retrievability span (Firbas 1995, 1992: 23-24), which was often not so transparent as in (b). Example (c) illustrates a final thematic, context-independent adverbial.

The pattern Trans $-R h-T h$ (13 instances in fiction, 4 in academic prose) mostly displays final thematic adverbials; (2) d. illustrates a final thematic object.

(2) a. She had an impulse now (James, 64)

b. They have a fire behind them (Davis)

c. Happened all the time in downtown Washington (Grisham)

d. that still seemed obscene to me (Grisham)

The pattern Trans - Th - Rh (35 instances in fiction, 21 in academic prose) reflects different structures displaying a thematic element between transition and the final element with rhematic function: ditransitive complementation, different configurations of adverbials, of objects and adverbials, and complex transitive complementation. Compare the examples listed under (3). The first element was mostly a pronominal object:

(3) a. giving the whole thing an importance (James 67)

b. When she had arrived that evening from the crematorium (James 67)

c. reduced him to a mere mortal (Grisham)

d. then looked at him for approval (Grisham)

e. of arriving in this way at some knowledge (Davis)

f. he has done so from the basis of dogmatic realism (Davis) 
g. (The size,) although making them more cumbersome in the trees, (made them less wary of ground-level sorties (Morris)

The pattern Initial $R h$ (5 instances in fiction, 8 in academic prose) is mostly realized by a presentation sentence ( 3 in fiction, all in academic prose, 4 of them with a passive verb).
a. A frayed and tattered trench coat fell to his knees (Grisham)
b. a gradual change of the human mind could be seen (Davis)
c. increasingly complex manoeuvres could be developed (Morris)

The remaining instances were two verbless sentences, which in fact could have been included in the category "other":

(5) Not a word from me as I quickly locked the doors,

Not a word from the eight litigators as they scrambled backward. (Grisham)

There was one presentation sentence realized by a copular predicate, cf. (6) a., whose semantics is rather exceptional in comparison with the typical semantics of these predicates. Here the notional complement of the copula explicitly expresses 'coming into existence' of a novel organism. However, another copular sentence with a context-independent subject, (6) b., whose semantics conveys one of the regular sentence meaning of copular sentences, viz. qualification, was included in the group "other".

(6) a. A hunting ape, a killer ape, was in the making (Morris)

b. A home base was necessary. (Morris)

I do not regard (6) b. as a presentation sentence because it conforms to this scale only in one feature, context-independence of the subject, but not in the presentational meaning of the verb: qualification can hardly be interpreted as implied appearance on the scene. Subject complements in copular predications nearly always have the FSP function of the rheme (cf. Uhlírová 1974), which was the case of all other copular clauses in my samples. Exceptional instances like (6) b. might be regarded as borderline cases between the presentation and the quality scales. This is supported by the Czech counterparts of (6) b., in which the content of the sentence can in the respective context be perspectived in both ways: Byla nutná nějaká domovská základna. [Was necessary some home base.] / Nějaká domovská základna byla nutná. [Some home base was necessary.].

The pattern DiaTh - Th, i.e. the placement of the most dynamic thematic element, the diatheme, before the least dynamic thematic element, the theme proper (Firbas 1992: 80-81; Svoboda 1983), 12 instances in fiction, 22 in academic prose, displays a deviation from the ordering according to the degree of communicative dynamism within one FSP function, the theme. All other patterns register 
deviant orderings between FSP functions. However, basic distribution of communicative dynamism involves not only the ordering of the three main FSP functions, theme, transition and rheme, but also the ordering within these functions. Compare Firbas's formulation:

"The principle of FSP arranges the sentence elements in a Th-Tr-Rh sequence. If asserting itself to the full extent, it even orders the elements within the $\mathrm{Th}$, the $\mathrm{Tr}$ and the $\mathrm{Rh}$ in accordance with a gradual rise in $\mathrm{CD}$, and induces the sentence to display what has been termed 'the basic distribution of CD'." (1992: 118)

This pattern appears to constitute a significant feature of the academic sample in contributing to its general characteristics: it is considerably more frequent in this text sort than in fiction. The pattern was mostly realized by two configurations: adverbial + pronominal subject and by two pronouns, relative and personal, as in (7) a. and b.

(7) a. i. But three months later it would have mysteriously disappeared. (James 65)

ii. in this book, we are not concerned with the massive cultural explosions (Morris)

iii. For the first time he sees real things. (Davis)

b. i. (He was extraordinarily knowledgeable in fields) of which she knew little. (James 64)

ii. (its content does not depend on the conditions) under which it can be verified (Davis)

iii. (Only by taking a hard look at the way) in which we have originated. (Morris)

iv. (by studying the biological aspects of the way) we behave as a species today (Morris)

Here a problem arises in the case of zero relatives: can they be regarded as diathemes when they have zero form? In general, the element that is elided is the most activated element. According to the definition of the different types of the diatheme (Svoboda 1989: 28-32) "může se připojit k vlastnímu rématu některé z předchozích vět" ([the diatheme] can connect to the rheme proper of a preceding clause), which is the case of relatives with antecedents in the rhematic section of the superordinate clause, as in (7) b. iv.

Another point to be noted in this connection is the configuration of two elements (mostly adverbials and subjects), neither of which could be classed as the theme proper, at the beginning of a sentence, such as (8).

(8) a. In the first centuries of Greek culture the strongest impulse had come from the immediate reality of the world. (Davis) 
b. on the top floor of a terraced house off Westbourne Grove Claudia Etienne lay in bed with her lover. (James 63)

This configuration frequently occurred in the academic samples. Where the remaining part of instances of this kind contained no deviation from the Trans $-\mathrm{Rh}$ order, as in (8), they were included among the clauses without deviations, with both elements being classed as diathemes. They are noteworthy in that they display two different dynamic semantic functions, a scene setting, realized by the adverbials, and a quality bearer realized by the subjects, performing one FSP function, that of the diatheme. This raises the question of the relationships between the dynamic semantic functions, their syntactic carriers (the clause elements) and the FSP functions: while two of the dynamic semantic functions, the phenomenon and the quality bearer, are exclusively realized by the subject, and can hence occur only once in a distributive field / a clause, the dynamic semantic function of diatheme appears to have two syntactic carriers, the subject and an adverbial, and is thus able to occur twice in the same distributive field. As regards the dynamic semantic function of specification, it corresponds to only one FSP function, the rheme, but within the rhematic section, since it can be realized by any nominal or adverbial element except the subject, it can occur several times as further specifications. The verb is again specific in this respect as it is the only syntactic element that can simultaneously carry two FSP functions, the transition and the rheme.

The pattern TransPrO - DiaTh/Th, constituted by a transition-proper oriented element (Firbas 1992: 77-79) followed by a thematic or diathematic element, reflects initial conjuncts and disjuncts; like deviations in the thematic section, this pattern is characteristic of academic writing, especially in the case of conjuncts.

(9) a. i. otherwise he took little interest in buying and selling (James 64)

ii. On the other hand, the difficulties of the separation could be clearly seen from the beginning. (Davis)

iii. Therefore, the animals and the plants were not essentially different from machines, (Davis)

b. i. Obviously this whole description is somewhat artificial (Davis)

ii. Essentially this was a hunting-group of males. (Morris)

Several examples contained both transition-proper oriented elements and two diathemes, cf. (10):

10. a. On the other hand in natural science the partition was for several centuries extremely successful (Davis)

b. In the Old World, on the other hand, ancestral apes were spreading over a wide forest area ... (Morris)

The last group, denoted "other" in Table 2, cannot be called a pattern as it contains miscellaneous instances whose classification did not lend itself to a clear-cut 
treatment. There were 4 such examples in fiction and 6 in academic writing. One of them has been mentioned in connection with the pattern $\mathrm{Rh}$ - Trans (- optional Th), cf. (6) b. Similarly the presentation or quality scale is not clear in (11) a.

(11) a. Several things happened together (Morris)

b. This partition has penetrated deeply in the human mind during the three centuries following Descartes. (Davis)

c. to formulate for the first time a trend in human thinking (Davis)

d. and I too became rigid (Grisham)

e. i. (The scraps were,) she saw, (lined with old letters (James 64)

ii. (Declan,) as Claudia admitted, (had an eye) (James 64)

f. With strong pressure on them to increase their prey-killing prowess (Morris)

In (11) a., there is again the possibility of both equivalents in Czech "Několik věcí se událo najednou" [Several things happened at-the-same-time $(\mathrm{Rh})]$ / "Najednou se událo několik věci" [At-the-same-time happened several things (Rh)]. There is yet a third possibility: "Událo se několik věcí najednou" [Happened several things at-the-same-time $(\mathrm{Rh})]$, which indicates an extended presentation scale (Chamonikolasová 2010).

Examples b. and c. have unclear FSP structure in the postverbal position. In b. the final temporal adverbial has heterogeneous composition comprising both context-dependent (Descartes) and context-independent (the numeral) elements. This together with the polyfunctionality of the final position of adverbials, which is the position of both thematic scene-settings and rhematic specifications, makes it an instance of potentiality. In c. the position of for the first time indicates a component of the rhematic section; however, the reversal of the usual ordering object - adverbial endows it with a lower degree of communicative dynamism. Example d. is a second instance - a borderline case. The two comment clauses listed under e. present the same problem as reporting clauses of direct speech: considered as self-contained units, they have the basic distribution of $\mathrm{CD}$, with the verb performing the dual function of Trans/Rh. However, they are not self-contained units: they derive from ordinary content clauses, hence the rheme may be sought

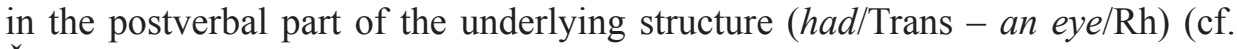
Řezníčková 2013: 109-114) As regards the last example (11) f., its FSP structure depends on how it is interpreted syntactically. If the prepositional phrase on them is assigned the function of postmodifer, cf. the expansion into a relative clause "that is on them", then the whole prepositional phrase is one syntactic unit, carrying one FSP function, that of the diatheme: with strong pressure on them to increase their prey-killing prowess, vital changes began to take place. If, however, it is regarded as an adverbial, there are two carriers of FSP functions, and two FSP functions, the diatheme and the theme, are to be distinguished. 


\section{Discussion of the results}

Considering the results summarized in the two Tables, the assumption of fewer deviations in academic writing than in fiction appears to have been fallacious. Table 1 shows that it is academic writing that displays considerably more deviations than fiction. Conceivably, this could have been expected as a concomitant feature of syntactic structures serving to convey complex semantic contents in a condensed way. A clause in academic writing rarely contains just three elements, such as $\mathrm{S}-\mathrm{V}-\mathrm{O}$, or $\mathrm{S}-\mathrm{V}-\mathrm{Adv}$. This is demonstrated by the first pattern in Table 2: thematic elements following a rhematic verb. The occurrence of this pattern is nearly twice as high in fiction, nearly a third of all the deviating patterns (29\%) against less than a fifth of all the deviating patterns (17\%) in the academic sample. Obviously the more elements have to be arranged in a sentence, the more deviations can be expected, especially in a language with grammatical word order.

As regards the other two assumptions, more deviations in the preverbal position in academic writing as compared with more deviations in the postverbal position in fiction, the figures in Table 2 appear to give them some support. Examples of the first three patterns, in which a thematic element follows the rheme, account for $77 \%$ ( 77 instances) in fiction against 42\% (42 instances) in academic writing. On the other hand, representation of the three patterns with a more dynamic element preceding the theme (initial $\mathrm{Rh}, \mathrm{DiaTh}-\mathrm{Th}, \mathrm{TransPrO}-\mathrm{Th}$ ) is higher in academic writing than in fiction: $52 \%$ (52 instances) as compared with $19 \%$ (19 instances). However, the initial assumption that this prevalence will be due to presentation sentences realized by initial rhematic subjects and a presentational verb envisaged only a part of the language facts, and a minor one: even though this structure is more common in academic writing, the prevalence is only moderate -8 instances ( $8 \%$ of all deviating instances) against $5(5 \%)$ in fiction. Moreover, the figures are too small to be conclusive. More support for the second assumption is found in the patterns showing deviations in the thematic section: in academic writing, clauses displaying diathemes or transition-proper oriented elements preceding themes account for $44 \%$ (44 instances of all deviating instances), as compared with $14 \%$ (14 instances) in fiction. Apart from the stylistic aspect, the zero realization form of the diatheme in the pattern DiaTh - Th raises doubts about the capacity of this form to perform the function of diatheme, and points to the need to specify, in addition to the FSP defining features of the theme and diatheme, also their realization forms. Another point arising in connection with the diatheme is the co-occurrence of two diathemes within the theme. This raises the question of the degrees of communicative dynamism of the two diathemes, according to which they could be placed in the interpretative arrangement.

In general, the results clearly show the close relationship between syntactic structure, which provides the carriers of syntactic functions, and the occurrence and arrangement of the respective FSP functions. 


\section{Conclusion}

According to the presented findings, deviations from the basic distribution of communicative dynamism are able to serve as a style marker and may provide a viable topic for more extensive research into the relationship between functional sentence perspective and style. Studies in this field carried out so far are concerned only with the stylistic aspects of the presentation sentence (Adam 2013a, 2013b; Rohrauerová 2015), which, together with the present study, does not exhaust the relationships between functional sentence perspective and style. Other FSP structures and functions remain for exploration, such as, to mention only a few, basic / deviant distribution of the components of the transition, simple vs. complex (homogeneous / heterogeneous) composition of carriers of FSP functions, especially of the rheme, context-independent subjects in the quality scale, and others. The stylistic aspect moreover extended research covering a larger variety of text sorts.

\section{References}

Adam, Martin (2013a) "Selected style markers of English biblical texts." Linguistica Pragensia 23 (2): 58-72.

Adam, Martin (2013b) Presentation Sentences. Brno: Masaryk University, Faculty of Education.

Chamonikolasová, Jana (2010) "Communicative perspectives in the theory of FSP." Linguistica Pragensia 20 (2): 86-93.

Firbas, Jan (1992) Functional Sentence Perspective in Written and Spoken Communication. Cambridge: Cambridge University Press.

Firbas, Jan (1995) "Retrievability span in functional sentence perspective." Brno Studies in English 21: $17-45$.

Firbas, Jan (2010) "On defining the theme in functionals sentences analysis.” In: Svoboda, Aleš, Jana Chamonikolasová and Ludmila Urbanová (eds.) Collected Works of Jan Firbas, Vol. 1. Brno: Masaryk University Press, 259-271.

Halliday, M. A. K. (1994) Introduction to Functional Grammar. London: Arnold.

Leech, Geoffrey N. (1983) Principles of Pragmatics. London and New York: Longman.

Quirk, Randolph, et al. (1985) A Comprehensive Grammar of the English Language. London and New York: Longman.

Rohrauer, Leona (2015) Presentation Sentences in Fiction and Academic Prose: A syntactico-semantic, FSP and textual view. Unpublished doctoral dissertation. Prague: Charles University, Faculty of Arts.

Řezníčková, Ivana (2013) Selected FSP Aspects of a Narrative Text: A study of the verb beyond transition. Ostrava: Ostravská univerzita v Ostravě.

Svoboda, Aleš (1983) “Thematic elements.” Brno Studies in English 15: 49-85.

Svoboda, Aleš (1989) Kapitoly z funkčni syntaxe (Chapters from functional syntax). Prague: Státní pedagogické nakladatelství.

Uhlírová, Ludmila (1974) “On the role of statistics in the investigation of FSP.” In: Daneš, František (ed.) Papers on Functional Sentence Perspective. Prague: Academia, 208-216. 


\section{Sources}

InterCorp Books available at <http://www.korpus.cz/intercorp > (last accessed 6 November 2014) Grisham, John (1998) The Street Lawyer. New York: Doubleday.

James, P. D. (1995) Original Sin. London: Faber and Faber.

Heisenberg, W. (2000) Physics and Philosophy: the revolution in modern science. Translated from German (Physik und Philosophie) by John Davis. London: Harper and Row.

Morris, D. (1969) The Naked Ape. New York: McGraw Hill Book Company.

LiBuŠE DušKovÁ is Professor Emerita of English Language at the Department of English Language and ELT Methodology, Charles University. Her books include Mluvnice současné angličtiny na pozadi češtiny (A Grammar of Contemporary English Against the Background of Czech), two volumes of Studies in the English Language and the recent volume From Syntax to Text: The Janus Face of Functional Sentence Perspective. She is the author of the translation of Vilém Mathesius' Obsahový rozbor současné angličtiny na základě obecně lingvistickém (A Functional Analysis of Present Day English on a General Linguistic Basis), editor of the English translation of Dictionnaire de linguistique de L'école de Prague (Dictionary of the Prague School of Linguistics) and chief editor of the international academic journal Linguistica Pragensia. Her recent research concentrates on the relations between syntax, functional sentence perspective and text.

Address: Prof. PhDr. Libuše Dušková, DrSc., Department of English Language and ELT Methodology, Faculty of Arts, Charles University, nám. Jana Palacha 2, 116 30, Prague 1, Czech Republic. [e-mail: libuse.duskova@ff.cuni.cz] 